\title{
An Understanding of Concepts of Line, Staff and Auxiliary in Organization
}

\author{
Dr. S. B. M. Marume ${ }^{1}$, E. Jaricha ${ }^{2}$, T. M. Chiunye ${ }^{3}$ \\ ${ }^{I} B A$, Hons BA, MA, MAdmin, MSoc Sc, PhD \\ ${ }^{2} B S c, M B A$, DPhil (Candidate) \\ ${ }_{3}^{3} B S c, M P A, D P h i l($ Candidate)
}

\begin{abstract}
According to L. D. White [1926], the business of government is transacted by means of an elaborate organization held together in a universal superior - subordinate relationship, and based on the principles of specialization. The central hierarchy comprises (a) the line; assisting the line are various units; some concerned with advisory and preparatory operations, known as staff, some concerned with house - keeping operations describes as the auxiliary agencies.
\end{abstract}

Keywords: business of government, elaborate organization, universal superior - subordinate relationship, principles or organization, line, staff and other auxiliary

\section{Introduction}

According to the literature available, the administrative organization of government institutions generally consists of three types of agencies, namely, line, staff and auxiliary. The distinction that exists between those three organization units lies in the nature of work performed by them. All this constitutes the subject matter of this article.

\section{Purpose Of Article}

The purpose is to define and illustrate the differences between line, staff and auxiliary and their interdependence.

\subsection{Meanings}

\section{Line And Staff}

The administrative organization of government consists of three types of agencies, namely,, line, staff and auxiliary. The distinction between these three organizational units lies in the nature of work done by them. The line agencies directly work for the achievements of the organizational purpose, the staff agencies advise and assist the line agencies in their activities, and the auxiliary agencies provide common house - keeping services to the line agencies.

According to $L$. D. White, the business of government is transacted by means of an elaborate organization held together in a universal superior - subordinate relationship, and based on the principle of specialization. The central hierarchy comprises the line; assisting the line are various units, some concerned with advisory and preparatory operations, known as staff, some concerned with house - keeping operations described as the auxiliary agencies. The line comprises the central element of any administrative system; staff and auxiliary agencies are necessary in a large and complex organization, but they are secondary. They serve the line. The distinction between line and staff in public administration is adopted from the military administration where it was developed first.

\subsection{Views of scholars}

The following views expressed by various scholars clearly bring out the line staff distinction and its relevancy

Pfiffner and Presthus: in general the distinction between staff and line follows that between direct and indirect labour, the direct line and the indirect staff

Oliver Sheldon: The staff organization may be described as a deliberate organization for thought, just as the line organization is the organization for execution

Dimock, Dimock and Koieng: Staff and line coordinates, operating not in a hierarchical relation to staff over line, but on a horizontal plane of authority and responsibility under the chief executive. A staff man who does not give commands to the line is ineffectual and a line man who does not understand and exercise a modicum of staff function is a failure 
Koontz and O'Donnell: Line and staff are characterizations of authority relationships and not departmental activities.

\subsection{Line agencies}

There are four types of line agencies in public administration

- Government departments

- Public corporations

- Government companies

- Independent regulatory commission IRC

The first three are found in all the countries of the world while the last one is a special feature of the administrative system of USA.

The line agencies have the following characteristic features

i. They directly carry out the function of accomplishing the sustentative of the organization.

ii. They are given authority to make decisions and issue orders and directives

iii. They directly come in contact with the people and provide them various services, regulate conduct, and collect taxes.

Thus, the line agencies are executive in nature and are subordinate divisions of operating responsibility working under the direct control, direction, and supervision of the chief executive.

According to L. D. White, major functions of the line agencies include:

- making decision

- taking responsibility

- interpreting and defending policy and operations

- maintaining production and seeking efficiency and economy.

\subsection{Staff agencies}

The important staff agencies of the government of India are:

1. Cabinet secretariat

2. Prime minister's office

3. Cabinet committees

4. Planning commission

5. Department of economic affairs

6. Administrative vigilance division

7. Staff inspection unit

The staff agencies have the following characteristic features.

1. They perform secondary or supportive functions, that is, assist the line in the accomplishment of organizational purpose.

2. They do not have the authority to make decisions and issue orders and directives. Their role os advisory in nature and they exercise some influence rather than authority

3. They do not come in contact with people directly. They function anonymously. According to the Brownlow commit of USA (1937), the staff should have a passion for anonymity

According to Mooney, the staff agencies perform three functions

i. Informative function, that is, collection and provision of information to the chief executive, research, study and enquiry.

ii. Advisory function, that is, advising the chief executive on making decisions

iii. Supervisory function that is, seeing that the chief executive's decision is implemented by the line agencies concerned.

Pfiffner says that the staff agencies perform the following functions

i. Advising, teaching and consultation

ii. Coordination

iii. Fact finding and research

iv. Contact and liaison

v. Assisting the line

vi. Exercising delegated authority from line 
vii. Planning

L. D. White has mentioned the following functions of staff agencies

1. to ensure that the chief executive is adequately and currently informed

2. to assists him in foreseeing problems and planning future programmes

3. to ensure that matters for his decision reach his desk promptly and to protect him against any hasty or ill considered judgments

4. to exclude every matter that can be settled elsewhere in the system

5. to protect his time

6. to secure means of ensuring compliance by subordinates with established policy and executive direction

According to Mooney, the staff is an expansion of the personality of the executive. It means more eyes, more ears, and more hands to aid him in forming and carrying out his plans. Pfiffner and Presthus have describer that staff as the alterego of the chief executive.

According to Pfiffner, staff agencies are of three kinds, namely

i. The general staff, which assist the chief executive in his administrative work, generally by advice, collection of information, research, and so on. The fundamental purpose of general staff is to act as a filter and funnel to the chief executive

ii. The technical staff, which advises the chief executive in technical matters and exercises functional supervision. It is also known as special staff or function staff

iii. The auxiliary staff, which provide common housekeeping services to the line agencies.

However, L. D. White and Willoughby do not include the auxiliary agencies under the category of staff agencies (auxilliary staff) and consider them as a separate and distinctive unit. White calls them as auxiliary services, while Willoughby refers to them as institutional or housekeeping services, John Gaus calls them auxiliary - technical staff services.

\subsection{Auxiliary agencies}

The important auxiliary agencies of the government of India are:

- $\quad$ Central public works department

- Law ministry/finance ministrylinformation and broadcasting ministry

- Union public service commission

- Parliamentary affairs department

- $\quad$ Director - general of supply and disposal

Like staff agencies, the auxiliary agencies also assist the line agencies in the accomplishment of organizations purpose and do not come in contact with the people. But, they differ from the staff agencies in the following respects.

i. The staff agencies advise the line agencies, while the auxiliary agencies provide common housekeeping services to the line agencies.

ii. The staff agencies have no operating responsibilities, while the auxiliary agencies do have operating responsibilities.

iii. The staff agencies do not exercise authority and do not make decisions, while the auxiliary agencies exercise limited authority and make decision in their own sphere.

iv. The staff agencies have multiple functions and wider jurisdiction than auxiliary agencies which are concerned with maintaining the line agencies

\subsection{Line staff conflicts}

Though line and staff units are indispensable in all government organizations and are meant to complement each other, the relationship between them is not always cordial and happy. The relations in practice between line and staff units are characterized by conflicts, clashes, tensions, suspicions and so on. The reasons for such a conflicting situation are as follows;

i. The staff agency, being close to the chief executive, tend to unsurp the authority of the agency

ii. The differences between line and staff officials in terms of age, status, outlook, experience, technical competence, and so on.

iii. The staff people usually adopt ivory-tower approach, that is, they suggest unrealistic plans and ideas to the line people who are more practical in their approach. Consequently, they do not care much to such suggestions, leading to misunderstanding and tension between the two.

iv. The tendency of the line officials to disown responsibility and blame the staff officials for mistakes 
v. The staff officials tend to discover the deficiencies in the work and procedures of line authorities.

Measures to reduce the conflict, rivalry and rancor in line - staff relationship are:-

i. The chief executive should clearly specify the nature of responsibilities of line and staff people. This enables him to hold them responsible for their mistakes

ii. The opportunities to exchange roles should be created, that is, there should be periodic transfer between the line and staff

iii. The chief executive should encourage both to get better acquainted with each other as well as with their mutual roles. He should highlight the desirability of close relationship between line and staff officials for accomplishing organizational purpose and objectives

iv. The line people should be given training in staff work and vice - versa. This enables them to know the proper aspects and dimension of their duties and responsibilities.

Moreover, matrix organization can be adopted to overcome the problem of line - staff controversy.

\section{Conclusion}

From the study, it is concluded that the administrative organization of government consisting of three types of agencies, namely, line, staff, these three organizational units lies in the nature of work performed by them, that is,

- line agencies directly work for the achievement of the organizational purpose;

- staff agencies advise and assist the line agencies, and

- the auxiliary agencies provide common house - keeping services to the line agencies.

\section{Bibliography}

[1]. C. I. Barnard; The functions of the Executive: Harvard University Press, Cambridge Massachusetts: 1964.

[2]. J. J. N. Cloete: Introduction to Public Administration: Pretoria; J. L. van Schaik, 1967: translation

[3]. M. E. Dimock and G. O. Dimock Public Administration (ed0: Holt, Rinehart and Winston Inc., New York, 1964.

[4]. L. Gulick and L. F. Urwick (eds): Papers on the Science of Administration: Institute of Public Administration; New York, 1937

[5]. F. M. Marx (ed): Elements of Public Administration: 2nd edition: Prentice - Hall, Inc., Englewood Cliffs, New Jersey, 1959.

[6]. Geoffrey Vickers: The Art of Judgement; A study of Policy - making: Chapman and Hall. Limited, London, 1965

[7]. N. Weiner: Cybernetics; Control and Communication in the Animal and the Machine: John Wiley and Sons: New York, 1948

[8]. J. E. Anderson, Public policy - making, New York: Holt, Rinechart and Winston, $2^{\text {nd }}$ edition, 1979.

[9]. T. R. Dye, Understanding public policy administration: Pretoria; J. L. van Schaik, 1978

[10]. W. Fox and Ivan H. Meyer: Public administration to public administration: $2^{\text {nd }}$ edition: Staples Press, Limited, London, 1966.

[11]. E. N. Gladden: An introduction to public administration; $2^{\text {nd }}$ edition: Staples Press, Limited, London, 1966.

[12]. E. N. Gladden: The essentials of public administration: London Staple Press, 1972.

[13]. R. A. Goldwin (ed) Bureaucrats, public analysis, statesmen; who leads? Washington, D. C. 1980.

[14]. Nicholas Henry, Public administration and public affairs, New Jersey, Prentice Hall Inc, 1975.

[15]. R. Levitt, implementing public policy, London, Croom Helm 1980.

[16]. R. T. Nakamura and F. Smallwood, the politics of policy implementation, New York: Saint Martin's Press, 1980.

[17]. S. B. M. Marume; SADCC administration of economic programmes with reference to food and agricultural programmes; unpublished PhD [Public Administration] thesis: California University for Advanced Studies, State of California, United States of America; October 31, 1988.

[18]. F. A. Nigro, Modern Public Administration, $2^{\text {nd }}$ edition, New York; International edition, 1970.

[19]. C. Pollitt, L. Lewis, J. Nigro and J. Pattern, Public policy theory and practice, Kent, Hodder and Stoughton in association with Open University Press, 1979. 